\title{
World Water Week 2015
}

\author{
Anna Tengberg ${ }^{1}$
}

Published online: 23 September 2015

(C) Springer Science+Business Media Dordrecht 2015

From 23-28 August, the World Water Week (WWW), one of the world's most influential conferences on water was organized in Stockholm (Sweden). The over 3300 participants took part in a broad discussion on current and future water research and management themes. 'Environment, Development and Sustainability' calls for contributions anchored in the main themes of this event, which are summarized in this editorial.

\section{Water for development}

The theme of the 2015 World Water Week was Water for Development, as 2015 is the target year for achieving the UN Millennium Development Goals (MDGs) that are being replaced by the post-2015 development agenda enshrined in the Sustainable Development Goals (SDGs) that will be adopted at the UN Sustainable Development Summit, September 25-27, 2015, in New York. Of the 17 SDGs, Goal 6: 'Ensure availability and sustainable management of water and sanitation for all' is directly related to water, but sustainable management of water resources is essential for achieving a large number of the SDGs, such as ending poverty and hunger, access to sustainable energy, inclusive and sustainable economic growth, combating of climate change, and sustainable management of terrestrial as well as marine ecosystems, to mention just a few.

The importance of water in the SDG agenda was highlighted by contributions on implementing SDGs in shared basins and freshwater ecosystems, and on indicators for measuring progress and ensuring implementation of the SDG on water and sanitation. More attention needs to be paid to water as an important driver of sustainable development and poverty eradication. Gender and social equity issues, and the rights of indigenous

Anna Tengberg

anna.e.tengberg@gmail.com

1 Lund University Centre for Sustainability Studies (LUCSUS), P.O. Box 170, SE-221 00 Lund, Sweden 
peoples need to be integrated into all water management efforts. It was considered imperative to build multi-stakeholder partnerships and coalitions to involve a broad range of actors and stakeholders in the implementation and delivery of the SDGs, including engaging with the private sector both to support implementation and to secure funding.

\section{Water, climate change and disaster risk reduction}

Linkages between climate change and water resources are receiving increased attention. The WWW closed with urging climate negotiators to ensure that water is thoroughly integrated in the global 2015 climate agreement expected from the 21 st Conference of the Parties (COP21) of the UNFCCC to be held in Paris in December 2015.

Water plays an important role in the continuum from climate change mitigation, to adaptation and disaster risk reduction (DRR). Sustainable management of water is important in, for example, promotion of renewable energy, such as hydropower and bioenergy, and reducing emissions from deforestation and forest degradation in developing countries (REDD), activities which all help mitigate climate change. To adapt to impacts of climate change, understanding of changes to water supply and the water cycle is crucial in the water and sanitation, agriculture, fisheries and aquaculture, and forestry sectors. Moreover, due to changes to the climate, the world is experiencing more frequent floods and other extreme, water-related weather events. These climate-water-disaster risk interlinkages should be framed in a preventive approach to water and disaster risk reduction. Managing change and strengthening resilience to climate and disaster risk, such as floods and droughts, including urban flooding and impacts on water, sanitation and hygiene services is what an increasing number of regions worldwide are confronted with. This also underlines the importance of unraveling linkages between the impact of climate change on water resources and political insecurity, and the role of transboundary water cooperation in the face of climate change to reduce risks of conflicts over limited water resources.

\section{Water and integrated approaches to natural resources management}

The water-energy-food nexus approach should be linked to sustainable food and agriculture and be framed within an intersectoral management context. The role of natural infrastructure is important, and there is a need to distinguish between the resource basewater, energy, land, soil, and associated ecosystem services - and the goals and interests of different sectors and stakeholders in society. Other innovative integrated natural resources management approaches discussed include the landscape approach to managing ecosystem services across scales and addressing trade-offs between, e.g., agricultural development and water security; certification of forest ecosystem services, such as water, freshwater ecosystems and human development; and joint management of water resources and forests in mosaic landscapes to ensure resilient landscapes and multiple socioeconomic and environmental benefits.

The importance of linking water resources management in terrestrial and marine ecosystems was also addressed by the 'Source to sea management' platform for sustainable growth and development. It focuses on the linkages along the land-river-coast-sea continuum, including the management of large rivers to secure functions of coastal ecosystems. Source to sea management contributes to achieving both SDG6 on availability and 
sustainable management of water and sanitation for all, and SDG14 on conservation of sustainable use of the oceans, seas and marine resources. This involves the application as well as strengthening of a number of existing integrated approaches to natural resources management, such as integrated water resources management (IWRM) and integrated coastal management (ICM).

\section{Financing sustainable water resources management}

It is important that water resources management gets access to climate change funding, such as funding for mitigation and adaptation from the Green Climate Fund (GCF) that was established at COP16 of the UNFCCC in Cancun in 2010. Priorities on water for the fund include cities, agriculture, forestry, resilience of Small Island Developing States (SIDS) and energy. Also funding of the water resources sector by the Global Environment Facility (GEF), the financial mechanism of all the Multilateral Environmental Agreements established in connection with the UN Conference on Environment and Development in Rio in 1992, should continue. The GEF has funded transboundary water management in a number of shared river basins, lakes and aquifers and also provides support to integrated natural resources management that integrates sustainable management of water, biodiversity and land resources.

Other important investment approaches to mainstream climate adaptation include the development of a climate bond certified standard for water investments. Moreover, new public and private sector delivery models have emerged to ensure sustainable finance for universal rural water services, including the role of Public-Private Partnerships (PPPs) and Payment for Ecosystem Services (PES) schemes. 